\title{
Morphological and histomorphometric evaluation of autogenous bone graft resorption in rabbits treated with alendronate sodium
}

\author{
Avaliação morfológica e histomorfométrica da reabsorção de enxertos ósseos \\ autógenos em coelhos usuários de alendronato de sódio
}

Teo Mario da ROSA a, Alexandre da Silveira GERZSONª, Diogo Souza Ferreira Rubim de ASSIS ${ }^{b}$, Cláudia Cristina BIGUETTI`, Mariza Akemi MATSUMOTO ${ }^{d}$, Eduardo Sanches GONÇALES ${ }^{c *}$

${ }^{a} U S C$ - Universidade Sagrado Coração, Bauru, SP, Brasil

'UFMA - Universidade do Maranhão, São Luis, MA, Brasil

'FOB - Faculdade de Odontologia de Bauru, USP - Universidade de São Paulo, Bauru, SP, Brasil

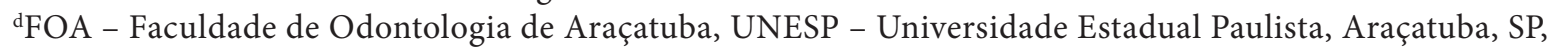

Brasil

\begin{abstract}
Resumo
Introdução: Durante o reparo de enxertos ósseos, diferentes taxas de reabsorção são mediadas pelos osteoclastos e podem ser afetadas pelos bisfosfonatos, que são drogas que agem como inibidores da reabsorção óssea. Objetivo: Avaliar a taxa de reabsorção dos enxertos ósseos de calota craniana de coelhos, com e sem o uso alendronato de sódio. Material e método: Trinta e dois coelhos Nova Zelândia foram divididos igualmente em 2 grupos (grupo controle e grupo alendronato de sódio) e subdivididos em 4 períodos (7, 14, 30 e 60 dias). O grupo controle não recebeu alendronato, enquanto os animais do grupo experimental receberam $4 \mathrm{mg}$ de alendronato de sódio por semana, em dose única, após a cirurgia. Um bloco de osso de diâmetro de $8 \mathrm{~mm}$ foi retirado o osso parietal e fixado com parafuso no osso parietal contralateral. Após cirurgia, nos períodos de 7, 14, 30 e 60 dias, os animais foram eutanasiados e as peças removidas para análise. Análises morfológica e histomorfométrica foram utilizados para comparar a espessura do enxerto e para avaliar a interface de osso recém formado entre o enxerto ósseo e o sítio receptor. Os testes de Wilcoxon e Mann-Whitney foram utilizados para as análises estatísticas. Resultado: Todos os enxertos repararam e integraram sem intercorrências; não foram detectadas diferenças estatisticamente significativas nas taxas de reabsorção ou deposição óssea, após a incorporação final do enxerto em ambos os grupos. Conclusão: Alendronato de sódio parece não diminuir a taxa de reabsorção, porém houve uma tendência de resultados melhores no grupo controle tanto na reabsorção quanto na neoformação óssea em enxertos ósseos autógenos de calota craniana de coelhos.
\end{abstract}

Descritores: Transplante ósseo; alendronato de sódio; reabsorção óssea.

\begin{abstract}
Introduction: Different rates of resorption are mediated by osteoclasts that may be affected by bisphosphonates during bone graft repair. Bisphosphonates are drugs that act as inhibitors of bone resorption. Objective: The aim of the present study was to evaluate the rate of resorption of skullcap grafts in rabbits with and without the use of alendronate sodium. Material and method: Thirty two New Zealand rabbits were divided into two groups (control group and alendronate group) and divided again into four periods (7, 14, 30 and 60 days). The control group did not receive alendronate, while animals of the experimental group received $4 \mathrm{mg}$ of alendronate sodium weekly after the surgery. An $8 \mathrm{~mm}$ diameter bone block was removed from the parietal bone and fixed by screws to the contralateral parietal bone. During the periods of 7, 14, 30 and 60 days, the animals had undergone euthanasia and samples were removed for further analysis. Morphological and histomorphometric tests were used to compare graft thicknesses and to evaluate the newly formed bone at the interface between the graft and receptor site. The Wilcoxon and Mann-Whitney tests were used for statistical analyses. Result: All grafts healed and integrated uneventfully and no statistically significant differences in resorption rates or bone deposition were detected after the final incorporation of the graft in both groups. Conclusion: Alendronate Sodium did not decrease the bone graft resorption rates, but there was a tendency for better results in the control group regarding the resorption and neoformation in autogenous calvarial bone grafts in rabbits.
\end{abstract}

Descriptors: Bone transplantation; alendronate sodium; bone resorption. 


\section{INTRODUCTION}

The success of rehabilitation using endosseous implants is dependent on bone quality and quantity ${ }^{1}$. When there is no adequate bone volume in the alveolar ridge, autogenous bone grafts are needed to correct this deficiency ${ }^{2,3}$. Bone graft healing and the final amount of bone formation depends on its remodeling capacity and factors like the amount of bone marrow in the bone graft, the vascularity of the receptor site and the stability of the graft ${ }^{4}$.

Remodeling is associated with resorption initiated by inflammation, which first acts upon the grafts and progresses to form granulation tissue (revascularization). It also promote osteoclastic activity on the recipient bed, removing areas of bone necrosis. At the same time, osteoprogenitor cells of the graft and the recipient area differentiate into osteoblasts and promote the incorporation of the graft to the recipient bed. The resorption rate depends on the properties of the recipient bed and the graft ${ }^{5}$. However, some drugs can interfere with this process, such as bisphosphonates (BPs) ${ }^{6}$.

BPs are inhibitors of osteoclastic bone resorption and have been used to control bone resorption in medical conditions such as bone metastases and osteoporosis ${ }^{7}$ with proven efficacy ${ }^{8,9}$. However, the use of BPs are related to osteonecrosis of the jaws (BRONJ), being complications associated with the use of intravenous BPs ${ }^{10}$ (zolendronic acid), but may also occur with oral BPs ${ }^{11}$ (alendronic acid). Further more, other adverse effects such as high permanence of drug in bone tissue, bone fractures, risk of gastrointestinal lesions, high permanence of drugs in the bone tissue ${ }^{12,13}$ may occur.

Alendronic acid is a bisphosphonate that has been used to prevent and treat osteoporosis by oral administration ${ }^{8}$ and it may influence the healing of bone grafts ${ }^{14-18}$, because its action involves osteoclastic cells and decreases the reabsorption process ${ }^{19}$. Similarly, the bone graft process depends on resorption and bone formation ${ }^{4}$. With the use of alendronic acid and the necessity of bone grafts for posterior rehabilitation, the aim of the present study was to evaluate the resorption rate of autogenous bone graft blocks during calvarial repair in rabbits treated with oral alendronate sodium.

\section{MATERIAL AND METHOD}

The present was approved by CEP/USC 147/09. Thirty-two New Zealand rabbits aged 6 to 10 months and weighing 3 to $5 \mathrm{~kg}$ were divided into four groups (alendronate group and control group) which received drinking water and solid chow on demand throughout the study, adapting to the time of surgery.

During the surgical process, the animals were anesthetized by intra muscular injection with xylazine hydrochloride $(0.25 \mathrm{ml} /$ $\mathrm{kg}$ ) and ketamine $(0.25 \mathrm{ml} / \mathrm{kg})$, followed by a prophylactic dose of antibiotics $(0.2 \mathrm{mg} / \mathrm{kg}$ of $10 \%$ eurofloxacin). A dose of metamizole $(0.33 \mathrm{ml} / \mathrm{kg})$ was used for the postoperative analgesia. With the animals anesthetized, the hairs were shaven on the frontoparietal region, disinfected by the use of iodine solution and received local infiltration anesthesia of mephivacaine hydrochloride and epinephrine 1:100.000. After incision and periosteal dissection, the bone was exposed and an osteotomy was performed using an $8 \mathrm{~mm}$ trephine bur (Alpha Instrumentos Cirúrgicos, Ribeirão Preto, SP, Brazil) mounted in a reduction handpiece 20:1 (Kavo, Joinville, SC, Brazil) and thrown by the dental implant motor (Driller, Capapicuiba, SP, Brazil) at the speed of 20,000 rpm under constant irrigation with $0.9 \%$ saline. The blocks were removed from the right parietal bone and adapted and fixed to the contralateral bone using $1.5 \mathrm{~mm}$ diameter and $4 \mathrm{~mm}$ long screws (Neoortho, Curitiba, PR, Brazil). The periosteum was repositioned using 4-0 polyglactin (Johnson \& Johnson, São Paulo, SP, Brazil) and 5-0 nylon sutures (Johnson \& Johnson, São Paulo, SP, Brazil).

During the post-operative period, the animals in the test group received $1 \mathrm{mg} / \mathrm{kg}$ alendronate sodium per week, once a day. To obtain the dose of the alendronic acid, the average weight of the animals was $4 \mathrm{~kg}$ and we ordered $4 \mathrm{mg}$ capsules of the drug diluted in $4 \mathrm{ml}$ of $0.9 \%$ saline were used to form a homogeneous mixture. The euthanasia of the animals occurred in the periods of 7, 14, 30 and 60 after the surgery by intravenous injection of $200 \mathrm{mg} / \mathrm{kg}$ of $3 \%$ sodium pentobarbital. The samples collected were labeled and stored in $10 \%$ formalin for 48 hours and then demineralized in $10 \%$ EDTA at pH 7.0 which was changed twice a week for 30 to 60 days. Next, they were rinsed under running water, dehydrated in alcohol, cleared in xylol and embedded in paraffin.

The sample slides in the alendronate and control groups were described according to the morphology and histomorphometry by measuring the thickness of the graft at 30 and 60 days in both groups. Three regions, defined according to Masson's trichrome staining, including almost all of the bone block fixed in the skullcap of the animals, were examined under 10x magnification with a Nikon microscope (Eclipse 80i, Melville, NY, USA) to estimate the bone density of the area using a score defined by a testing system. The points in bone under formation and the points out of the bone under formation were counted at 7 and 14 days. The histological image sections were analyzed using the Microsoft Office Picture Manager ${ }^{\circledR}$, and the testing system was placed over the image to start counting. The testing system had 216 points distributed as lines measuring $100 \mu \mathrm{m}$ in length each and printed on a clear A4 sheet. After counting points per field, the results were added to determine the total number of lines in and out of the bone formation interface. The percentage of the bone area under formation in the interface was estimated following Melo**.

\section{RESULT}

In the morphological evaluation, the control group on the $7^{\text {th }}$ day showed low cellularity in the bone graft, richly vascularized interface, presence of primary bone from the recipient bed without supporting capacity and discrete resorption areas. (Figure 1a). The alendronate sodium group was similar to the group control, but was associated with discrete resorption areas (Figure 2a). On the $14^{\text {th }}$ day, the bone interface between the recipient bed and the graft of the control group was filled with remodeling bone and there was predominance of primary bone and trabecular organization (Figure $1 \mathrm{~b}$ ), while in the alendronate group, there was primary bone deposition on the recipient bed and graft

\footnotetext{
** Melo A. Estudo da reparação do alvéolo dental de ratos Wistar preenchido com osso autógeno particulado após exodontia [tese]. São Paulo: Instituto de Ciências Biomédicas da Universidade de São Paulo; 2007.
} 

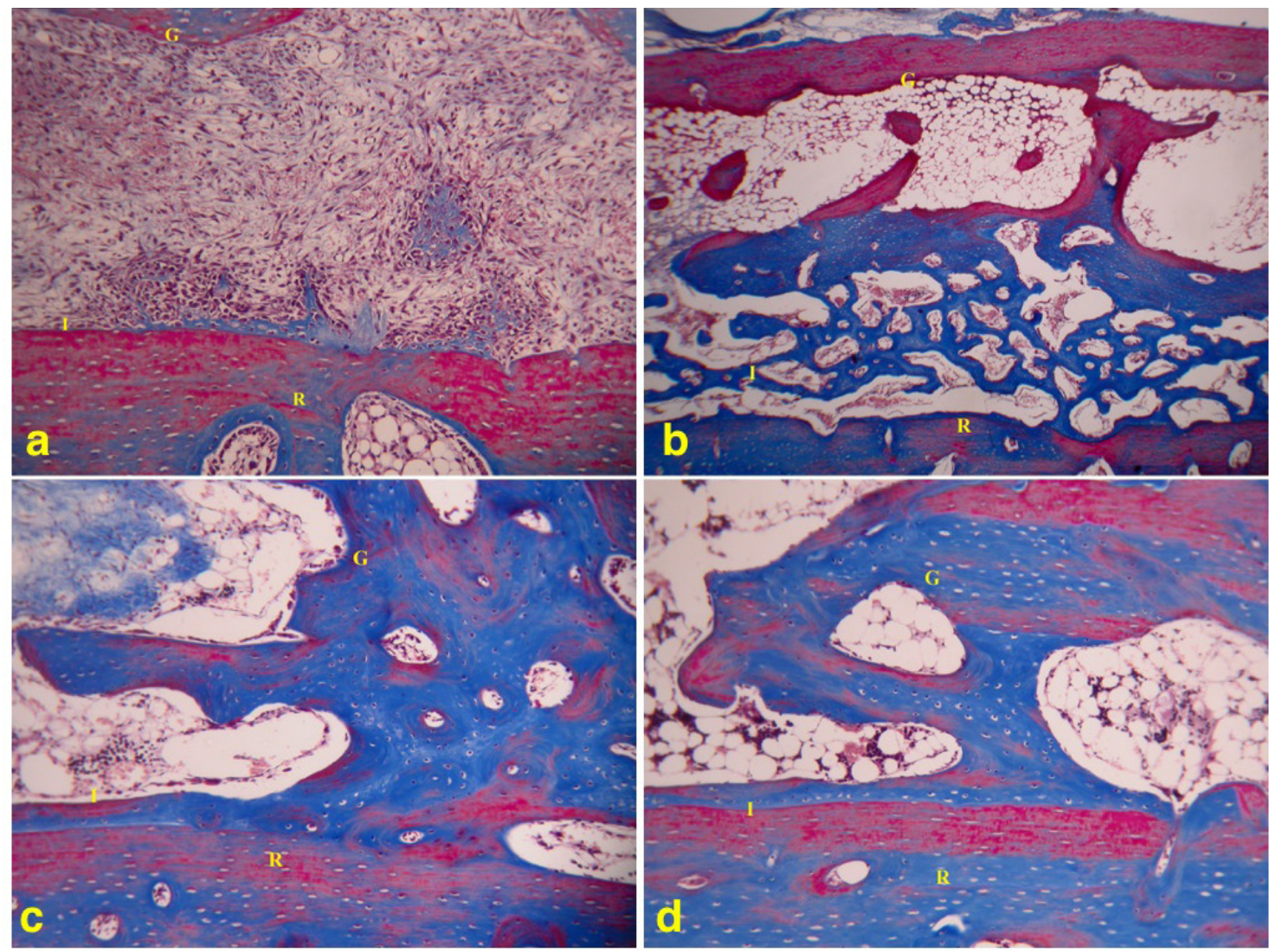

Figure 1. Control group. (a) 7 days - (I): interface area; (G) graft and (R) recipient bed. (b) 14 days - (I) interface area; (G) graft and (R) recipient bed. (c) 30 days) - (I) interface area; (G) graft and (R) recipient bed. (d) 60 days - (I): interface area; (G) graft and (R) recipient bed. $240 \times 180 \mathrm{~mm}$ $(300 \times 300$ DPI $)$.

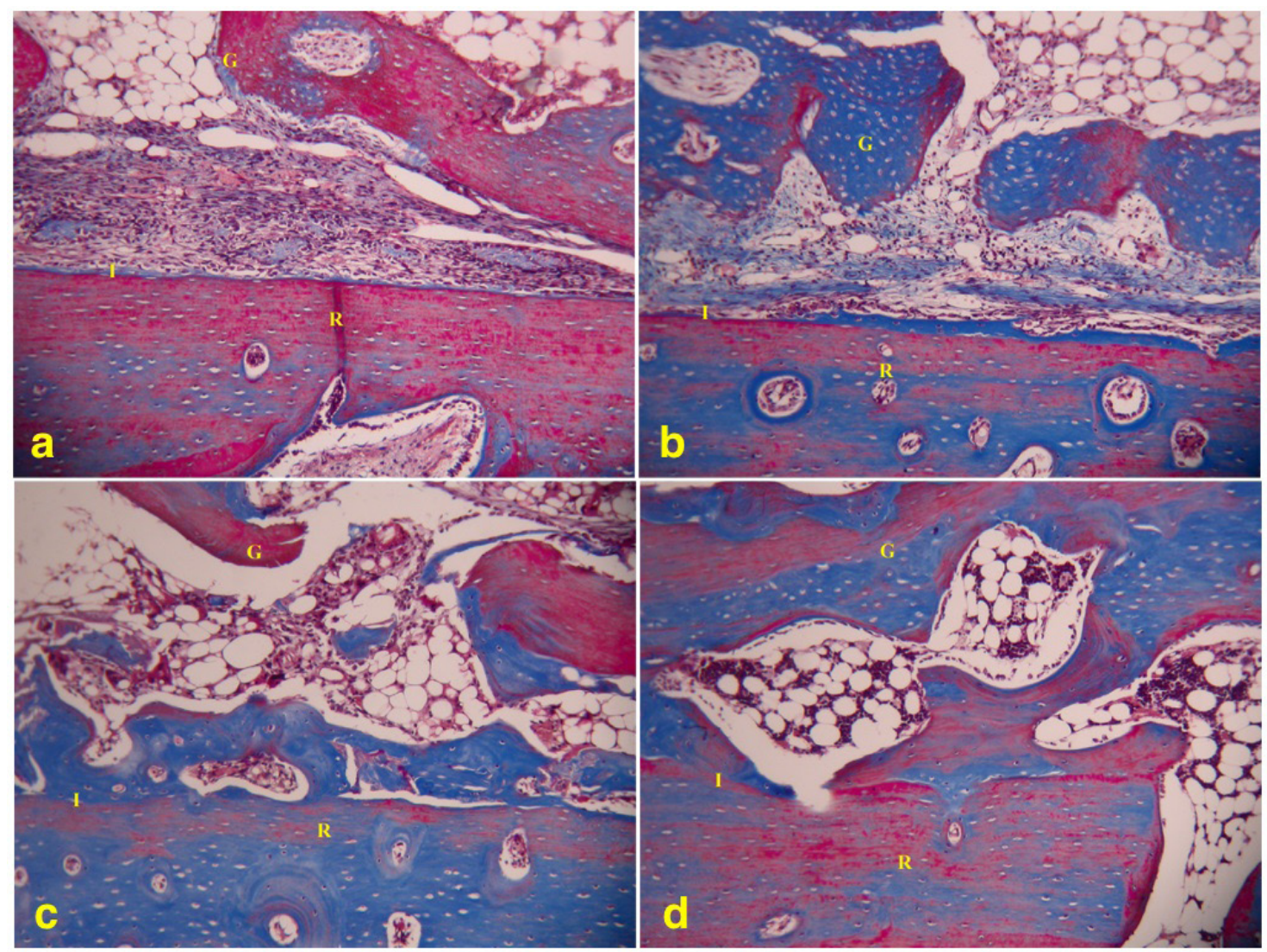

Figure 2. Alendronate group (a) 7 days - (I) interface area; (G) graft and (R) recipient bed. (b) 14 days) - (I): interface area; (G) graft and (R) recipient bed. (c) 30 days - (I) interface area; $(G)$ graft and (R) recipient bed. (d) 60 days - (I) interface area; $(G)$ graft and (R) recipient bed. $240 \times 180 \mathrm{~mm}(300 \times 300 \mathrm{DPI})$. 
surfaces (Figure $2 \mathrm{~b}$ ). On the 30 th day, the graft was incorporated to the recipient bed and the interface between the recipient bed and the graft was remodeled for both the control (Figure 1c) and alendronate (Figure 2c) groups, but there was predominance of mature and vascularized bone in the control group. On the 60th day, the control group showed the incorporation of the bone graft and intense remodeling (Figure 1d), while the alendronate group preserved the original architecture of the graft bone block and showed discrete remodeling and osteoclastic activity (Figure 2d).

The histomorphometric analysis was 30 and 60 days after the surgery. On the $30^{\text {th }}$ day, the resorption was $10 \%$ greater in the control group than in the alendronate group, while in the 60 day period, there was $36 \%$ resorption in the control group and $16.50 \%$ resorption in the alendronate group. However, there was no statistical difference between the groups in two the periods when the resorption rate (Wilcoxon test) and bone graft thickness (Mann-Whitney test) (Table 1) were analyzed.

In evaluation of bone formation, the analyses were made in the initial periods of the study ( $7^{\text {th }}$ and $14^{\text {th }}$ day). The average percentage of newly formed bone between the recipient site and the graft was of $4 \%$ and $6 \%$ on the $7^{\text {th }}$ day for the control and alendronate groups, respectively. On the $14^{\text {th }}$ day the average was of $24 \%$ in the control group and $11 \%$ in the alendronate group. The Mann-Whitney test was applied to compare the percentage of new bone formation between the alendronate and the control groups, and there was no statistical difference between those groups at $7^{\text {th }}$ day. However, on the $14^{\text {th }}$ day there was greater bone formation in the control group (Figure 3).

\section{DISCUSSION}

The neo bone formation process is controlled by osteoblasts that can activate osteoclasts, which are resorptive bone cells that act through the release of cytokines. Osteoclasts secret substances and

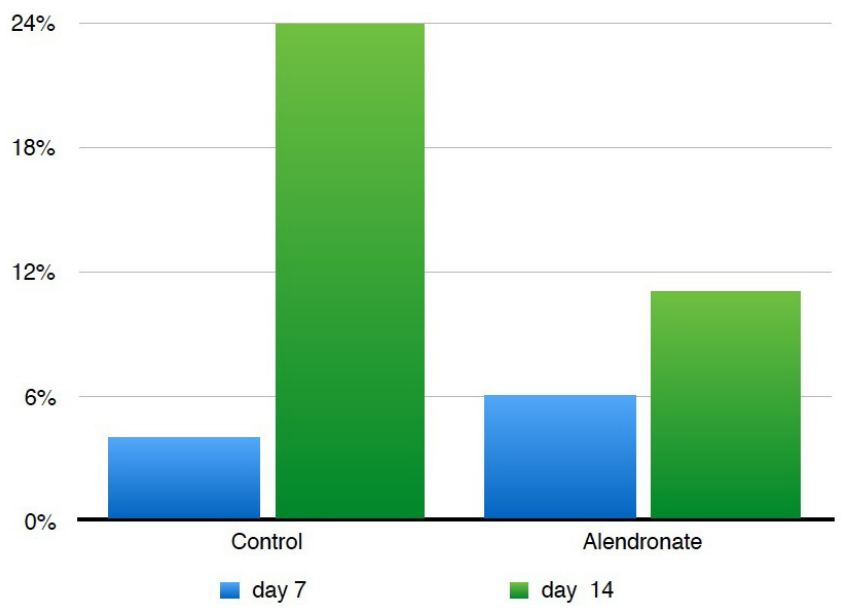

Figure 3. Average (\%) of newly formed bone between the recipient site and the graft. $361 \times 270 \mathrm{~mm}(72 \times 72 \mathrm{DPI})$.

Table 1. Histomorphometric analysis of graft block thickness before and after surgery $(\mathrm{P}>0.05)$

\begin{tabular}{|c|c|c|c|c|c|c|}
\hline \multicolumn{7}{|c|}{ Graft thickness } \\
\hline & Time point & $\begin{array}{c}\text { Thickness at } \\
\text { surgery }\end{array}$ & $\begin{array}{c}\text { Mean at surgery } \\
\text { (4 rabbits) }\end{array}$ & $\begin{array}{c}\text { Postoperative } \\
\text { thickness }\end{array}$ & $\begin{array}{l}\text { Mean postoper- } \\
\text { ative thickness } \\
\text { (4 rabbits) }\end{array}$ & $\begin{array}{l}\text { Resorption } \\
\text { index }\end{array}$ \\
\hline \multirow{5}{*}{ Alendronate } & & $\mathrm{A}: 1.9 \mathrm{~mm}$ & & $\mathrm{~A}: 1.7 \mathrm{~mm}$ & & \\
\hline & 30 days & $\mathrm{B}: 1.8 \mathrm{~mm}$ & $1.92 \mathrm{~mm}$ & $\mathrm{~B}: 1.3 \mathrm{~mm}$ & $1.6 \mathrm{~mm}$ & $16.66 \%$ \\
\hline & & $\mathrm{C}: 1.9 \mathrm{~mm}$ & & $\mathrm{C}: 1.7 \mathrm{~mm}$ & & \\
\hline & & $\mathrm{D}: 2.1 \mathrm{~mm}$ & & $\mathrm{D}: 1.7 \mathrm{~mm}$ & & \\
\hline & & $\mathrm{E}: 1.8 \mathrm{~mm}$ & & E: $1.0 \mathrm{~mm}$ & & \\
\hline \multirow{4}{*}{ Control } & 30 days & $\mathrm{F}: 2.0 \mathrm{~mm}$ & & $\mathrm{~F}: 1.7 \mathrm{~mm}$ & & \\
\hline & & $\mathrm{G}: 1.8 \mathrm{~mm}$ & $1.92 \mathrm{~mm}$ & $\mathrm{G}: 1.7 \mathrm{~mm}$ & $1.42 \mathrm{~mm}$ & $26.04 \%$ \\
\hline & & $\mathrm{H}: 2.1 \mathrm{~mm}$ & & $\mathrm{H}: 1.3 \mathrm{~mm}$ & & \\
\hline & & $\mathrm{A}: 1.9 \mathrm{~mm}$ & & $\mathrm{~A}: 1.7 \mathrm{~mm}$ & & \\
\hline \multirow{4}{*}{ Alendronate } & 60 days & $\mathrm{B}: 2.1 \mathrm{~mm}$ & $2.0 \mathrm{~mm}$ & $\mathrm{~B}: 1.7 \mathrm{~mm}$ & $1.67 \mathrm{~mm}$ & \\
\hline & & $\mathrm{C}: 2.0 \mathrm{~mm}$ & & $\mathrm{C}: 2.0 \mathrm{~mm}$ & & $16.50 \%$ \\
\hline & & $\mathrm{D}: 2.0 \mathrm{~mm}$ & & $\mathrm{D}: 1.0 \mathrm{~mm}$ & & \\
\hline & & $\mathrm{E}: 1.9 \mathrm{~mm}$ & & $\mathrm{E}: 1.0 \mathrm{~mm}$ & & \\
\hline \multirow{3}{*}{ Control } & 60 days & $\mathrm{F}: 2.0 \mathrm{~mm}$ & & F: $1.7 \mathrm{~mm}$ & & \\
\hline & & $\mathrm{G}: 2.0 \mathrm{~mm}$ & $1.95 \mathrm{~mm}$ & $\mathrm{G}: 1.3 \mathrm{~mm}$ & $1.25 \mathrm{~mm}$ & $35.89 \%$ \\
\hline & & $\mathrm{D}: 1.9 \mathrm{~mm}$ & & $\mathrm{H}: 1.0 \mathrm{~mm}$ & & \\
\hline
\end{tabular}


this process stimulates differentiation ${ }^{* * *}$. Therefore some drugs, such as bisphosphonates, could act in osteoclastics cells, changing the remodeling process ${ }^{4}$.

Bisphosphonates act by inhibiting bone resorption. They influence osteoclastic activity and prevent cell recruiting and differentiation, in addition to reducing their longevity. Since they are incorporated into the bone matrix under mineralization, together with mineral ions such as calcium, bisphosphonate molecules become part of the bone structure that will be resorbed during natural bone remodeling. Osteoclasts die by structural fragmentation, with no enzyme or molecular spilling. Therefore, bisphosphonates contribute to control accelerated bone turnover ${ }^{20-23}$.

Studies for the treatment of osteoporosis with alendronate showed that it is able to increase bone mass by reducing bone turnover and promoting greater bone formation through resorption ${ }^{24}$. Therefore, the use of bisphosphonates in individuals that require bone grafts could be indicated.

The animal model used in the present study has been clearly established in the literature and it is well documented that rabbit metabolism is 3 or 4 times faster than human metabolism, thus 30 and 60 days could correspond to 3 and 6 months in humans $s^{25}$, after which the biological and mechanical conditions are adequate for the placement of osseointegrated implants ${ }^{1}$. The calvarium was chosen for the anatomic size of the region and the possibility of removing a bone block and fixing it to another site without complicated surgeries. Alendronate concentrates in areas of intense osteoclastic activity ${ }^{21}$ and it is not uniformly distributed to bones, which explains why our results, that are due to the reduction of graft resorption and the consequent reduction of replacement with new bone. These results were not statistically significant in the present study, because its administration, less than 4 years at a dose of $35 \mathrm{mg} /$ week or two years at $70 \mathrm{mg} /$ week, results in little or no effect on angiogenesis ${ }^{26}$.

Many indexes are used to estimate bone resorption after bone graft procedures ${ }^{27}$ and the present study investigated whether the administration of alendronate sodium might lead to lower indexes since it could decrease osteoclastic activity of bone resorption in patients with osteopenia and osteoporosis and perhaps stop those processes ${ }^{15}$. The present results did not show any statistically

\footnotetext{
*** Gonçales ES, Sant'Ana E, Cury M, Ferreira O Jr, Carvalho PSP. A terapia com bisfosfonatos e a osseointegração. In: Carvalho PSP. Osseointegração: visão contemporânea da implantodontia. São Paulo: Quintessence; 2009. p. 21- 30.
}

significant difference in bone grafts between groups, both at 30 and 60 days of incorporation into the recipient bed, as also reported in another study ${ }^{16}$.

The possible effect of alendronate sodium was also evaluated on the interface of new bone formation between the graft and the recipient bed at different time periods (when that separation is still observable at 7 and 14 days), because the graft-reception bed interface cannot be observed at 30 and 60 days. At 7 days, there were no statistically significant differences between groups, whereas at 14 days, there was greater and statistically significant new bone formation in the group that did not receive alendronate. BPs contribute to the control of accelerated bone turnover ${ }^{23}$, and it is believed that the interference of alendronate in the modulation of bone resorption delayed the deposition of new bone in the alendronate group, probably because of its effect on the osteoblasts ${ }^{4}$, which justified greater bone formation at $14^{\text {th }}$ days in the control group.

The alendronate did not negatively affect the graft incorporation and did not compromise the final result at 30 and 60 days, which confirms the histological viability of the grafts, but it is not indicated for patients that will undergo bone graft procedures. Although the oral BPs do not seem to substantially affect the bone graft remodeling, the discontinuation of the use of alendronate is recommended ${ }^{8} 3$ months before surgeries in patients that have taken it orally for less than 3 years, and that simultaneously take corticoids chronically, or in patients that have been using it for more than 3 years. The decision to discontinue or not should be made by the physician that prescribed $\mathrm{it}^{28}$.

Bone resorption is greater in the first year after reconstruction and in the first year after implant loading and decreases significantly after that ${ }^{14}$. Therefore, studies should be conducted to evaluate the use of treatment in the first year after graft procedures and implant placement, as well as the use of different doses and administration before surgery. Their findings may contribute to improving the efficacy of our surgery protocols.

\section{CONCLUSION}

Alendronate sodium does not appear to decrease the rate of resorption of bone grafts, since there was a tendency for better results in the control group, both in the resorption and neoformation in autogenous calvarial bone grafts in rabbits.

\section{REFERENCES}

1. Matsumoto MA, Nary H Fo, Francischone CE, Consolaro A. Microscopic analysis of reconstructed maxillary alveolar ridges using autogenous bone grafts from the chin and iliac crest. Int J Oral Maxillofac Implants. 2002 Jul-Aug;17(4):507-16. PMid:12182293.

2. Levin L, Nitzan D, Schwartz-Arad D. Success of dental implants placed in intraoral block bone grafts. J Periodontol. 2007 Jan;78(1):18-21. http://dx.doi.org/10.1902/jop.2007.060238. PMid:17199534.

3. Toker H, Ozdemir H, Ozer H, Eren K. Alendronate enhances osseous healing in a rat calvarial defect model. Arch Oral Biol. 2012 Nov;57(11):1545-50. http://dx.doi.org/10.1016/j.archoralbio.2012.06.013. PMid:22795567.

4. Marx RE. Bone and bone graft healing. Oral Maxillofac Surg Clin North Am. 2007 Nov;19(4):455-66, v. http://dx.doi.org/10.1016/j. coms.2007.07.008. PMid:18088897. 
5. Johansson B, Grepe A, Wannfors K, Hirsch JM. A clinical study of changes in the volume of bone grafts in the atrophic maxilla. Dentomaxillofac Radiol. 2001 May;30(3):157-61. http://dx.doi.org/10.1038/sj.dmfr.4600601. PMid:11420628.

6. Rogers MJ, Gordon S, Benford HL, Coxon FP, Luckman SP, Monkkonen J, et al. Cellular and molecular mechanisms of action of bisphosphonates. Cancer. 2000 Jun;88(12 Suppl):2961-78. http://dx.doi.org/10.1002/1097-0142(20000615)88:12+<2961::AID-CNCR12>3.0.CO;2-L. PMid:10898340.

7. Filleul O, Crompot E, Saussez S. Bisphosphonate-induced osteonecrosis of the jaw: a review of 2,400 patient cases. J Cancer Res Clin Oncol. 2010 Aug;136(8):1117-24. http://dx.doi.org/10.1007/s00432-010-0907-7. PMid:20508948.

8. Stoch SA, Saag KG, Greenwald M, Sebba AI, Cohen S, Verbruggen N, et al. Once-weekly oral alendronate 70 mg in patients with glucocorticoidinduced bone loss: a 12-month randomized, placebo-controlled clinical trial. J Rheumatol. 2009 Aug;36(8):1705-14. http://dx.doi.org/10.3899/ jrheum.081207. PMid:19487264.

9. Klaus J, Haenle MM, Schroter C, Adler G, von Boyen G, Reinshagen M, et al. A single dose of intravenous zoledronate prevents glucocorticoid therapy-associated bone loss in acute flare of Crohn's disease, a randomized controlled trial. Am J Gastroenterol. 2011 Apr;106(4):786-93. http://dx.doi.org/10.1038/ajg.2011.59. PMid:21386830.

10. Bagan J, Scully C, Sabater V, Jimenez Y. Osteonecrosis of the jaws in patients treated with intravenous bisphosphonates (BRONJ): A concise update. Oral Oncol. 2009 Jul;45(7):551-4. http://dx.doi.org/10.1016/j.oraloncology.2009.01.002. PMid:19251474.

11. Ruggiero SL, Dodson TB, Fantasia J, Goodday R, Aghaloo T, Mehrotra B, et al. American Association of Oral and Maxillofacial Surgeons position paper on medication-related osteonecrosis of the jaw-2014 update. J Oral Maxillofac Surg. 2014 Oct;72(10):1938-56. http://dx.doi. org/10.1016/j.joms.2014.04.031. PMid:25234529.

12. Marx RE, Sawatari Y, Fortin M, Broumand V. Bisphosphonate-induced exposed bone (osteonecrosis/osteopetrosis) of the jaws: risk factors, recognition, prevention, and treatment. J Oral Maxillofac Surg. 2005 Nov;63(11):1567-75. http://dx.doi.org/10.1016/j.joms.2005.07.010. PMid:16243172.

13. Vestergaard P. Occurrence of gastrointestinal cancer in users of bisphosphonates and other antiresorptive drugs against osteoporosis. Calcif Tissue Int. 2011 Dec;89(6):434-41. http://dx.doi.org/10.1007/s00223-011-9539-4. PMid:22002678.

14. Agholme F, Aspenberg P. Experimental results of combining bisphosphonates with allograft in a rat model. J Bone Joint Surg Br. 2009 May;91(5):670-5. http://dx.doi.org/10.1302/0301-620X.91B5.21867. PMid:19407306.

15. Altundal H, Gursoy B. The influence of alendronate on bone formation after autogenous free bone grafting in rats. Oral Surg Oral Med Oral Pathol Oral Radiol Endod. 2005 Mar;99(3):285-91. http://dx.doi.org/10.1016/j.tripleo.2004.05.022. PMid:15716833.

16. Altundal H, Sayrak H, Yurtsever E, Göker K. Inhibitory effect of alendronate on bone resorption of autogenous free bone grafts in rats. J Oral Maxillofac Surg. 2007 Mar;65(3):508-16. http://dx.doi.org/10.1016/j.joms.2005.11.054. PMid:17307600.

17. Möller B, Wiltfang J, Acil Y, Gierloff M, Lippross S, Terheyden H. Prevention of the surface resorption of bone grafts by topical application of bisphosphonate on different carrier materials. Clin Oral Investig. 2014 Dec;18(9):2203-11. http://dx.doi.org/10.1007/s00784-014-1202-9. PMid:24562699.

18. Toker H, Ozdemir H, Ozer H, Eren K. A comparative evaluation of the systemic and local alendronate treatment in synthetic bone graft: a histologic and histomorphometric study in a rat calvarial defect model. Oral Surg Oral Med Oral Pathol Oral Radiol. 2012 Nov;114(5 Suppl):S146-52. http://dx.doi.org/10.1016/j.0ooo.2011.09.027. PMid:23063391.

19. Giger EV, Castagner B, Leroux JC. Biomedical applications of bisphosphonates. J Control Release. 2013 Apr;167(2):175-88. http://dx.doi. org/10.1016/j.jconrel.2013.01.032. PMid:23395668.

20. Drake MT, Clarke BL, Khosla S. Bisphosphonates: mechanism of action and role in clinical practice. Mayo Clin Proc. 2008 Sep;83(9):103245. http://dx.doi.org/10.4065/83.9.1032. PMid:18775204.

21. Igarashi K, Mitani H, Adachi H, Shinoda H. Anchorage and retentive effects of a bisphosphonate (AHBuBP) on tooth movements in rats. Am J Orthod Dentofacial Orthop. 1994 Sep;106(3):279-89. http://dx.doi.org/10.1016/S0889-5406(94)70048-6. PMid:8074093.

22. Dimitrakopoulos I, Magopoulos C, Karakasis D. Bisphosphonate-induced avascular osteonecrosis of the jaws: a clinical report of 11 cases. Int J Oral Maxillofac Surg. 2006 Jul;35(7):588-93. http://dx.doi.org/10.1016/j.ijom.2006.02.022. PMid:16687238.

23. Iwase M, Kim KJ, Kobayashi Y, Itoh M, Itoh T. A novel bisphosphonate inbibits inflammatory bone resorption in rat osteolysis model with continuous infusion of polyethylene particles. J Orthop Res. 2002 May;20(3):499-505. http://dx.doi.org/10.1016/S0736-0266(01)00155-3. PMid:12038623.

24. Green J, Clézardin P. Mechanisms of bisphosphonate effects on osteoclasts, tumor cell growth and metastasis. Am J Clin Oncol. 2002 Dec;25(6 Suppl 1):S3-9. http://dx.doi.org/10.1097/00000421-200212001-00002. PMid:12562045.

25. Yazawa M, Ogata H, Kimura A, Nakajima T, Mori T, Watanabe N. Basic studies on the bone formation ability by platelet rich plasma in rabbits. J Craniofac Surg. 2004 May;15(3):439-46. http://dx.doi.org/10.1097/00001665-200405000-00019. PMid:15111806.

26. Hughes DE, Wright KR, Uy HL, Sasaki A, Yoneda T, Roodman GD, et al. Bisphosphonates promote apoptosis in murine osteoclasts in vitro and in vivo. J Bone Miner Res. 1995 Oct;10(10):1478-87. http://dx.doi.org/10.1002/jbmr.5650101008. PMid:8686503.

27. Alberius P, Klinge B, Isaksson S. Management of craniotomy in young rabbits. Lab Anim. 1989 Jan;23(1):70-2. http://dx.doi. org/10.1258/002367789780886858. PMid:2724917.

28. Migliorati CA, Casiglia J, Epstein J, Jacobsen PL, Siegel MA, Woo SB. Managing the care of patients with bisphosphonate-associated osteonecrosis. J Am Dent Assoc. 2005 Dec;136(12):1658-68. http://dx.doi.org/10.14219/jada.archive.2005.0108. PMid:16383047. 


\section{CONFLICTS OF INTERESTS}

The authors declare no conflicts of interest.

\section{${ }^{*}$ CORRESPONDING AUTHOR}

Eduardo Sanches Gonçales, Departamento de Cirurgia, Estomatologia, Patologia e Radiologia, Faculdade de Odontologia, USP - Universidade de São Paulo, Rua Octávio Pinheiro Brizola, 975, 17012-901 Bauru - SP, Brasil, e-mail: eduardogoncales@usp.br

Received: August 28, 2015 Accepted: June 1, 2016 